\title{
ROLE OF SCRAPE CYTOLOGY IN THE DIAGNOSIS OF OVARIAN NEOPLASM AND CYTOHISTOLOGICAL CORRELATION OF OVARIAN NEOPLASSM.
}

\section{Dr Rina Kumari*}

\section{Dr Pankaj Kumar} Suman

\section{Dr Satyendra}

\section{Kumar}

\section{Dr R.K. Mishra}

Senior Resident/Tutor Department of Pathology, J L N medical college Bhagalpur. ${ }^{*}$ Corresponding Author

Senior Resident/Tutor Department of Pathology, J L N medical college Bhagalpur.

Assistant Professor \& Head Department of Pathology J L N medical college Bhagalpur

Professor Department of Pathology J L N medical college Bhagalpur

ABSTRACT AIM:To determine the role of scrape cytology in the diagnosis of ovarian neoplasm MATERIAL AND METHOD: This was a prospective study at jlnme duration of study was from nov 2019 to march 2020 on 100 solid/solid-cystic ovarian neoplasms sent in $10 \%$ buffered formalin, then stained with hematoxylin and eosin or Papanicolaou stains. Cytological results were compared with the histological diagnosis taking the latter as the gold standard. RESULT: Among the 100 cases, the standard histopathological diagnosis confirmed 61 as benign, 5 as borderline and 34 as malignant lesion. The diagnostic concordance between cytological and histo pathological study was observed in 97 of the 100 cases. Characteristic cytological pattern was noted in various types of surface epithelial, sex cord stromal and germ cell tumors. The technique had limited value in mucinous tumors to distinguish borderline cases from invasive carcinoma. CONCLUSIONS: IOC is a good complement to histopathology in the study of ovarian neoplasms, particularly in developing countries like ours, where the facility of frozen sections is often not available. Adequate knowledge on cytohistological correlation of ovarian scrape cytology may phase out the use of cryostat in intraoperative diagnosis of ovarian neoplasms.

KEYWORDS : Scrape Cytology, Histopathology, Ovarian Neoplasm, Cyto-histological Correlation.

\section{INTRODUCTION}

Ovarian cancer accounts for $3-4 \%$ of cancer in women. Ovarian mass for cytology can be approached by laparoscope and ultrasound-guided aspiration, however there are controversial views regarding their safety and has been discouraged since puncture of cystic carcinoma might cause intraperitoneal seeding of tumor cells. Here are two most commonly used intraoperative diagnostic procedure:1) Tissue smear technique i.e. imprint cytology, scrape cytology and squash cytology. 2) Frozen section. Rapid intraoperative diagnosis of the nature of ovarian tumors guides surgeons who has two management options: (1) Benign and borderline cases fertility conserving surgery/minimal access surgery is preferred in young patients. (2) Malignant cases complete surgical staging is done which involves total hysterectomy with bilateral salpingooophorectomy, partial omentectomy and retroperitoneal lymphnode sampling. Tumor debulking/cytoreduction Radiotherapy in Stage 3 and stage 4 carcinoma.

\section{METHOD AND MATERIAL}

This was prospective study of 100 ovarian neoplasm which includes solid, solid-cystic and cystic neoplasm in study. Fresh gross speciemen were examined for present of cyst, capsular breach, papillary growth and any solid growth. Scraping obtained from fresh cut surface of tumor preserved in $10 \%$ buffered formalin, smear uniformly on the glass slide. Smear was immediately in $90 \%$ ethyl alcohol and stained with $\mathrm{H}$ SE stain.

Various cytological techniques

- Imprint method

- FNAC method

- Scrape method

The results were examined with final diagnosis in each cases and cases with discordant diagnosis were reviewed.
Total cases of ovarian neoplasm

\begin{tabular}{|l|l|l|}
\hline Bengin & Borderline & Malignant \\
\hline $60 \%$ & $5 \%$ & $35 \%$ \\
\hline
\end{tabular}

Benign cases of ovarian neoplasm

\begin{tabular}{|l|l|}
\hline Benign & No of cases \\
\hline Serous cystadenoma & 20 \\
\hline Mucinous cystadenoma & 10 \\
\hline Corpous luteal cyst & 15 \\
\hline Mature teratoma & 10 \\
\hline fibrothecoma & 4 \\
\hline Struma ovarii & 1 \\
\hline
\end{tabular}

Malignant cases of ovarian neoplasm

\begin{tabular}{|l|l|}
\hline Malignant & No of cases \\
\hline Serous cystadenocarcinoma & 17 \\
\hline $\begin{array}{l}\text { Mucinous } \\
\text { cystadenocarcinoma }\end{array}$ & 10 \\
\hline Germ cell tumor & 4 \\
\hline Sex -cord tumor & 1 \\
\hline Met & 3 \\
\hline Borderline & 5 \\
\hline
\end{tabular}

Cyto-histopathological correlation of ovarian neoplasm

\begin{tabular}{|c|c|c|c|}
\hline \begin{tabular}{|l|} 
No of \\
cases
\end{tabular} & Final Diagnosis & $\begin{array}{l}\text { Cytological } \\
\text { diagnosis }\end{array}$ & $\begin{array}{l}\text { Cytological } \\
\text { and } \\
\text { histological } \\
\text { cor -relation }\end{array}$ \\
\hline 20 & Serous cystadenoma & $\begin{array}{l}\text { Serous } \\
\text { cystadenoma }\end{array}$ & $20 / 20$ \\
\hline 17 & $\begin{array}{l}\text { Serous } \\
\text { cystadenocarcinoma }\end{array}$ & \begin{tabular}{|l|} 
Serous \\
cystadenocarci \\
noma(16) \\
Serous \\
cystadenoma(1)
\end{tabular} & $16 / 17$ \\
\hline
\end{tabular}




\begin{tabular}{|c|c|c|c|}
\hline 10 & $\begin{array}{l}\text { Mucinous } \\
\text { cystadenoma }\end{array}$ & $\begin{array}{l}\text { Mucinouscystad } \\
\text { enoma(9) } \\
\text { Mucinous } \\
\text { cystadenocarci } \\
\text { noma(1) }\end{array}$ & $9 / 10$ \\
\hline 10 & $\begin{array}{l}\text { Mucinous } \\
\text { cystadenocarcinoma }\end{array}$ & $\begin{array}{l}\text { Mucinous } \\
\text { cystadenocarci } \\
\text { noma(9) } \\
\text { Mucinouscystad } \\
\text { enoma(1) }\end{array}$ & $9 / 10$ \\
\hline & Corpous luteal cyst & & $15 / 15$ \\
\hline & Mature teratoma & & $10 / 10$ \\
\hline & $\begin{array}{l}\text { Fibrothecoma } \\
\text { Struma ovarii }\end{array}$ & & $\begin{array}{l}4 / 4 \\
1 / 1\end{array}$ \\
\hline & Germ cell tumor & & $4 / 4$ \\
\hline & Sex-cord tumor & & $1 / 1$ \\
\hline 3 & Borderline & $\begin{array}{l}\text { Borderline } \\
\text { Mucinous } \\
\text { cystadenoma(4) } \\
\text { Borderline } \\
\text { serous } \\
\text { cystadenoma(1) }\end{array}$ & $5 / 5$ \\
\hline
\end{tabular}

\section{DISCUSIONS}

The intraoperative cytological examination was first introduced by Dudgeon and Patrick in 1927. Ovarian masses are frequently being subjected to SS and FS examination so as to determine the extent of surgery required, and complete resection along with removal of draining lymph nodes can be done in a single surgery.

There are several advantages of IOC over frozen sections which have been attested by different authors.

They are: rapidity of preparation which is not at the expense of accuracy; simple and inexpensive method; excellent preservation of cellular details without freezing artifacts; no loss of tissue as with the cryostat; (5) possibility of identifying focal, macroscopically undetectable neoplastic lesions in large tissue fragments; possibility of examining adipose, necrotic and calcified tissue; diagnosis of malignancy when the tissue is limited in quality, and avoidance of contamination and safe handling.

There were limitations of IOC in the diagnosis of tumors with low malignant potential borderline tumor and in mucinous tumors, which require histological architecture evaluation and adequate histological sampling.

In our study, we analysed the scrape cytology of ovarian neoplasms sent in formalin. In spite of utilizing formalin fixed specimens, architecture and cell morphology remained well preserved causing no interference in cytological interpretation.

Khunamornpong et al. studied role of scrape cytology of ovaries in intraoperative consultation of ovarian lesions and found it to be a useful rapid cytodiagnostic tool. Similar to our findings, their study also revealed that it was the borderline group which showed inconsistent results especially mucinous tumors.

A more accurate diagnosis would require histologic architecture evaluation and extensive tissue sampling.

On examining 4 cases of the germ cell tumors, 1 cases of granulosa cell tumors, and 10 cases of mature teratoma was accurately diagnosed by cytological examination. Our findings were supported by Shahid et al.8 and Khunamornpong and
Siriaunkgul15, who also found $100 \%$ diagnostic accuracy of cytological examination in detecting germ cell tumor and sex cord tumor.

\section{CONCLUSIONS}

In this study, high specificity and PPV were observed on SS during intraoperative cytology for ovarian neoplasms although HPE remains the gold standard. Scrape cytology is a simple, quick, accurate, inexpensive adjunctive cytodiagnostic technique and its routine utilization in ovarian lesions could aid in expanding the knowledge of cytology of ovarian neoplasms.

Photo

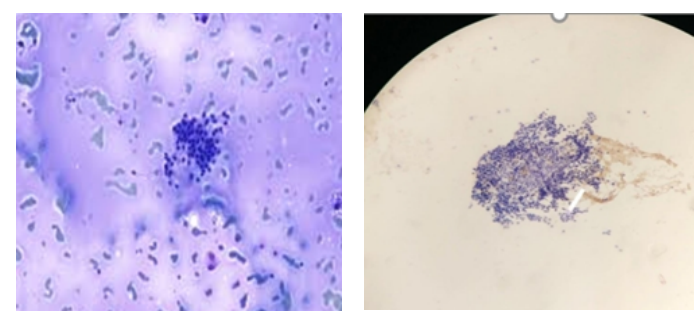

Scrapes smear showing benign thyroid follicular cells against $a$ thin colloid background.

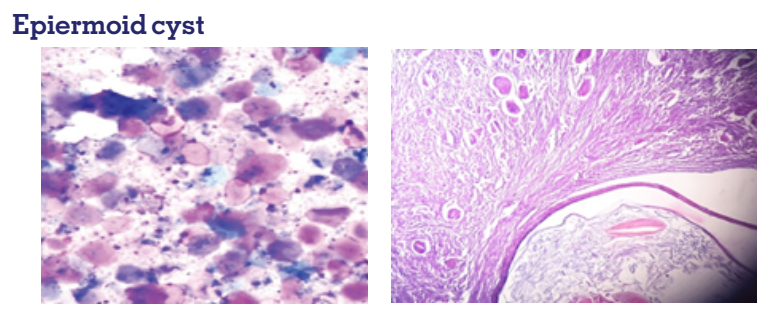

Scrape smear showing anucleated squames, cyst macrophages and few inflammatory cells

\section{MUCINOUS CYSTADENOCARCINOMA}

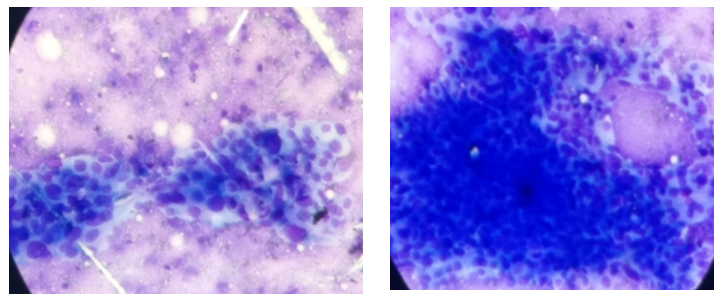

Highly cellular LG smear showing sheets of malignant cells and few scattered tumor cells having moderate to abundant vacuolated cytoplasm and nuclear overcrowding eccentric pleomorphic nuclei and occasional prominent nucleoli

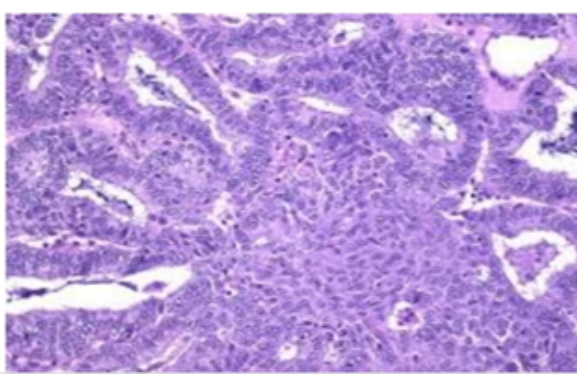

HPE showing malignant cells having dense eosinophilic cytoplasm. The nuclei stratified, large with coarse chromatin, and some contain prominent nucleoli.

\section{REFERENCES}

1. Shidham VB, Dravid NV, Grover S, Kher AV. Role of scrape cytology in rapid intraoperative diagnosis. Value and limitations. Acta Cytol $1984 ; 28: 477-82$ 
2. Rao S, Sadiya N, Joseph LD, Rajendiran S. Role of scrape cytology in ovarian neoplasms.J Cytol 2009;26:26-9.

3. Khunamornpong S, Siriaunkgul S. Scrape cytology of the ovaries: Potential role in intraoperative consultation of ovarian lesions. Diagn Cytopathol 2003;28:250-7

4. Shidham VB, Dravid NV, Grover S, Kher AV. Role of scrape cytology in rapid intraoperative diagnosis. Value and limitations. Acta Cytol 1984;28:477-82.

5. Prabhakar BR, Maingi K: Ovarian tumours prevalence in Punjab. Indian J Pathol Microbiol 1989; 32: 276-281.

6. Russell P: Surface epithelial-stromal tumors of the ovary; in Kurman RJ (ed): Blaustein's Pathology of the Female Genital Tract, ed 4. New York, Springer, 1994, pp 705-782

7. Michael CW, Lawrence WD, Bedrossian CWM:Intraoperative consultation in ovarian lesions: a comparison between cytology and frozen section. Diagn Cytopathol 1996; 15: 387-394.

8. Kontozoglou TE, Cramer HM. The advantages of intraoperative cytology Analysis of 215 smears and review of the literature. Acta Cytol 1991;35:154-64.

9. Stewart CJ, Brennan BA, Koay E, Naran A, Ruba S. Value of cytology in the intraoperative assessment of ovarian tumors: A review of 402 cases and comparison with frozen section diagnosis. Cancer Cytopathol 2010;118:127-36.

10. Rahmani K, Moradi-Lakeh M, Mansori K, Bidokhti F, AsadiLari M. global inequalities in incidence and mortality of ovarian cancer and associated factors: an ecological study. Alzheimers Park Res Ther. 